\title{
Niche separation between two closely related species of the genus Lasiambia Anonym., 1937 (Diptera: Chloropidae)
}

\author{
Разделение ниш у Авух близких видов \\ poAa Lasiambia Anonym., 1937 (Diptera: Chloropidae)
}

\author{
E.P. Nartshuk \\ Э.П. Нарчук
}

Zoological Institute, Russian Academy of Sciences, Universitetskaya nab., 1, St. Petersburg 199034 Russia. E-mail: chlorops@zin.ru Зоологический институт Российской академии наук, Университетская наб., 1, Санкт-Петербург 199034 Россия

Key words: Diptera, Chloropidae, Lasiambia, nishe separation.

Ключевые слова: Diptera, Chloropidae, Lasiambia, разделение ниш.

Abstract. Habitat and types of feeding of larvae of the genus Lasiambia Anonym., 1937 are analyzed. Larvae of Lasiambia as opposite to most Chloropidae are not phytophagous and not associated with Poaceae grasses. Two groups of species are separated. The first - larvae are saprophagous in a broad sense. The second includes species, larvae of which are carnivorous. Two closely related species are compared: L. palposa (Fallén, 1820) and L. coxalis (von Roser, 1840). Adults of these species are very similar and distinguished only on the structure of male postabdomen. Larvae of common L. palposa feed in egg pods of many different species of Acrididae, which lay eggs in ground. Larvae of rare L. coxalis feed eggs of Acrididae of a genus Chrysochraon, which lay eggs in plant stem. Character of alimentary nishe is correlated with numbers and extent of areal of these species.

Резюме. Проанализированы места обитания и типы питания кичинок в роде Lasiambia Anonym., 1937, которые в отличие от большинства Chloropidae не фитофаги и не связаны со злаками. Выделены 2 группы видов. У первой мичинки сапрофаги в широком понимании. У второй мичинки хищники, питающиеся яйцами насекомых. Сравниваются 2 близких вида, L. palposa (Fallén, 1820) и L. coxalis (von Roser, 1840), имаго которых сходны по внешней морфологии и разцичаются по наличию / отсутствию мембранозных мешков в прегенитальной области самцов. Аичинки L. palposa питаются яйцами многих видов саранчовых, отложенных в землю. Аичинки L. coxalis - яйцами видов только одного рода саранчовых Chrysochraon, которые откмадывают их в стебли растений. Широта пищевой ниши коррелирует с численностью и протяженностью ареалов этих видов.

The genus Lasiambia Anonymous in Imperial Institute of Entomology, 1937 includes 18 species in the Palaearctic according to the Cataloque [Nartshuk, 1984], where species are listed in the genus Fiebrigella Duda, 1921 with two subgenus Fiebrigella and Lasiambia. Later all Palaearctic species of the genus were considered in the genus Lasiambia [Tschirnhaus, 1992]. Habitats of larvae are known for some species. Larvae of Lasiambia as opposite to most Chloropidae are not associated with grasses and not phytophagous. There are 2 groups of species which larval habitats are known: species with saprophagous larvae in a broad sense (probably micromycetophagous and necrophagous as well) and species with carnivorous larvae. The first group includes 5 species. Larvae of $L$. albidipennis (Strobl, 1893) live in damaged plant stems together with other insects [Séguy, 1934; Koçak et al., 2009]. Larvae of L. baliola Collin, 1946 and L. brevibucca (Duda, 1933) develop in rotten wood, especially broad leaved wood, sap flows of damaged trees and in root holes [Collin, 1946; Allen, 1981; Godfrey, 1998]. Lasiambia conicola (Hering, 1941) was reared from stem of plant Conium maculatum L. (Apiaceae) [Hering, 1941]. Larvae of L. fycoperda (Becker, 1910) develop in damaged fruits of Ficus carica (Moraceae) [Silvestri, 1917].

The second group includes species with carnivorous larvae feeding on egg masses of insects. Larvae of L. mantivora Nartshuk, 2010 were reared from ootheca of Mantis religiosa Linnaeus, 1758 [Nartshuk, Sánches, 2010]. Lasiambia theryi (Séguy, 1946) and L. picardi (Séguy, 1946) are reared from Mantidae oothecae as well [Séguy, 1946]. Larvae of L. palposa (Fallén, 1820) live in egg pods of Acrididae and feed on eggs. Following species of Acrididae were recorded as hosts ${ }^{1}$ : Chorthippus biguttulus Linnaeus, 1758, C. albomarginatus De Geer, 1773, C. apricarius Linnaeus, 1758, Stenobothrus eurasius Zubovski, 1898, S. nigromaculatus Herrich.-Schäffer, 1840, Omocestus viridulus Linnaeus, 1758, Aeropedellus variegates Fischervon Waldheim, 1848 [Frauenfeld, 1863; Bezrukov, 1922; Shapinsky, 1923; Zakhvatkin, 1954; Nartshuk, 1972). Lasiambia coxalis (von Roser, 1840) was reared only once from egg masses of Chrysochraon dispar Germar, 1834 (Acrididae) in thistle stem [Hennig, 1941]. I received additional reared material of the species.

Galls of last year of Lipara spp. on Phragmites australis were collected in Staraya Russa southern of Lake Il'men in Veliky Novgorod Region (Russia) in 10-17 of May 2010.

\footnotetext{
${ }^{1}$ I use here name host, as some authors considered these Lasiambia species as parasites. Indeed larvae of these species live inside egg pods, but they feed egg by egg, not develop inside of a egg. Therefore it is more correctly considered these larvae as carnivorous.
} 

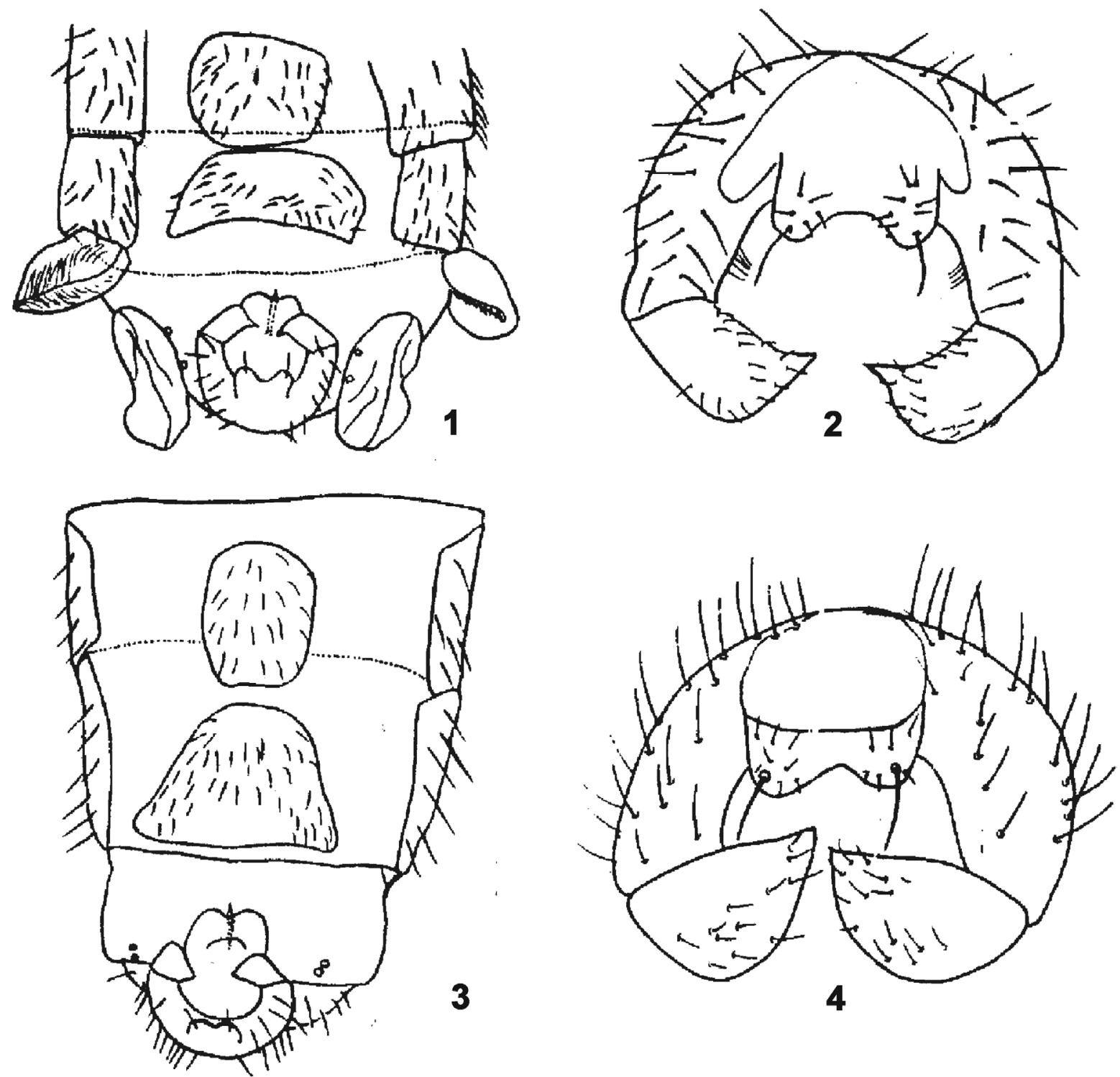

Figs 1-4. Lasiambia, details of structure.

1-2 - L. coxalis (von Roser, 1840); 3-4-L. palposa (Fallén, 1820). 1, 3 - tip of male abdomen, view below; 2, 4- male genitalia, epandrium. Рис. 1-4. Lasiambia, детали строения.

1-2 - L. coxalis (von Roser, 1840); 3-4 - L. palposa (Fallén, 1820). 1, 3 - вершина брюшка самца, виА снизу; 2, 4- гениталии самца, эпандрий.

Galls were collected near small salt lakes which in the past were used for extraction of food salt. Now this place is a balneology health resort. At present these lakes feed from artificial fountain drilled in 1840. Water of the fountain named Murav'evski contains 20 gram of mineral salt on a litre.

Galls were put in glass vessels, 19 galls in each. Two species of gall makers Lipara lucens Meigen, 1830 and L. pullitarsis Doskočil et Chvála, 1971 were reared from galls. Two common species of Chloropid inquilines Cryptoneva flavitarsis (Meigen, 1830) (36 specimens) and Calamoncosis minima (Strobl, 1893) (10 specimens) were reared from galls as well. Besides Anthomyzidae: 6 males, 9 females of Anthomyza gracilis (Fallén, 1823); some Cecidomyiidae; 14 specimens ( 7 males, 7 females) of bees Colletidae: Hylaeus pectoralis Förster, 1871 (Hymenoptera:
Apoidea), which usually nests in old Lipara galls and 2 specimens of parasites of Lipara: Stenomalina liparae (Giraud, 1863). All listed species are recorded for the first time for Veliky Novgorod Region (Russia).

Absolute unexpectedness was appearing of 6 specimens ( 1 male and 5 females) of Lasiambia coxalis (von Roser, 1840). A larva of Chrysochraon sp. was found in the same glass some days later. I collected Lipara galls on Common reed (Pragmites australis) during many years in different localities for rearing Chloropidae and received L. coxalis for the first time.

Lasiambia palposa and L. coxalis are closely related species. They are similar each another in all external characters and may be distinguished only on structure of male postabdomen. Lasiambia coxalis has two pairs of membranous vesicules between $5^{\text {th }}$ tergite of abdomen 
and pregenital sclerite (Figs 1, 2). These vesicules are usually situated inside of abdomen and turn outside in precopulation period. Lasiambia coxalis is rare species. Only a few specimens of $L$. coxalis are in the collection of the Zoological Institute RAS (ZIN, St. Petersburg, Russia): northern Ural Mountains (Mt. Neroika); Labytnangi, Tyumen Region; Yakutia, eastern of Yakutsk. Lasiambia coxalis was described from Germany (Würtemberg) and I have seen some specimens from France. Membranous vesicules is absent in male postabdomen of $L$. palposa (Figs 3,4$)$. The species is rather common and there are numerous specimens in the collection of ZIN from most territory of Russia from St. Petersburg to Irkutsk and Yakutia, Estonia and Mongolia.

Larvae of both species feed on Acrididae eggs. Ecological difference between these two closely related species lies in the fact that larvae of common species L. palposa feed on egg pods situated in ground, and larvae of rare species $L$. coxalis feed on eggs of Acrididae situated in herbaceous stem. Only species of Chrysochraon (Acrididae) lay eggs in the plant stem in the Palaearctic, and L. coxalis has one host species. Lasiambia palposa was reared from egg pods of different Acrididae, laying eggs in the ground. Ecological niche of larvae of L. palposa is wider, egg pods of many Acrididae are in the ground; ecological niche of larvae of $L$. coxalis is significantly narrower, egg masse are in plant stem. Probably these ecological features exert some effect on numbers and geographical distribution of species.

\section{Acknowledgements}

I thank Yu.V. Astafurova (ZIN) for determination of bees and E.V. Tselikh (ZIN) for determination of parasitic wasp. Collection of ZIN was used during preparing of the paper.

The investigation was supported by the Ministry of Education and Science of the Russian Federation, the Russian Foundation for Basic Research (grant 13-04-00639) and programme of Presidium RAS "Living nature: modern status and problems of development".

\section{References}

Allen A.A. 1981. The two British species of Lasiambia End. (Dipt., Chloropidae) in SE London. Entomologist's Monthly Magazine. 117: 144.

Bezrukov J.G. 1922. A brief report on the work of the Omsk laboratory of the Siberian Entomological Bureau in 1919-1922. Izvestiya Sibirskogo Entomologicheskogo Byuro.1: 26-30 (in Russian).

Collin J.E. 1946. The British genera and species of Oscinellinae. Transactions of the Royal Entomological Society of London. 97: 117-148.

Frauenfeld G., von. 1863. III. Verschiedene Metamorphosen. Verhandlungen der zoologische-botanische Gesellschaft Wien. 13: 12-1236.

Godfrey A. 1998. The Diptera of Moccas Park National Nature Reserve. Dipterist Digest (Second Series). 5: 44-48.

Hennig W. 1941. Neues über parasitische Dipteren. Arbeiten über morphologische und taxonomische Entomologie. Berlin. 8(3): 196-200.

Hering E.M. 1941. Eine neue Halmfliege aus dem Burgenland (Diptera, Chloropidae). Zeitschrift für Pflanzenkrankheiten. 51(1): 43-44.

Koçak E., Özdemir M., Zlobin V.V. 2009. Insects associated with the endemic species Heracleum platytaenium Boiss. (Apiaceae) with new records for the Turkish fauna. Turkish Journal of Zoology. 33: 245-247.

Nartshuk E.P. 1972. Predatism and parasitism in the evolution of chloropid flies (Diptera, Chloropidae). Zoologicheskii Zhurnal. 51: 1342-1352 (in Russian with English summary).

Nartshuk E.P. 1984. Fam. Chloropidae. In: Catalogue of Palaearctic Diptera, Vol. 10. Clusiidae - Chloropidae. (Á. Soós, L. Papp eds). Budapest: Akadémiai Kiadó: 222-298.

Nartshuk E.P., Sánchez I. 2010. A new species of Lasiambia Sabrosky (Diptera, Chloropidae) parasite from Mantis oothecae. Boletín de la Sociedad Entomológica Aragonesa. 46: 83-86.

Séguy E. 1934. Diptères (Brachycères), Muscidae Acalypterae et Scatophagidae. Faune de France. 28. Paris. 832 p.

Séguy E. 1946. Trois Chloropides nouveaux parasites d'oothèques d'Orthoptères. Encyclopédie Entomologique. Série B. II. Diptera. Vol. 10. Paris: $5-7$.

Shapinsky D.V. 1923. Biological observations on the Acrididae of the Chelyabinsk district, Orenburg province. Izvestia Moskovskogo entomologicheskogo obshchestva. 2: 26-29 (in Russian).

Silvestri F. 1917. Descrizioni di una specie di Oscinosoma osservato in fruttescenze di caprifico. Bollettino Del Laboratorio Di Zoologia Generale E Agrarian Della R. Scuola Superiori D'agricoltura in Portici. 12: $147-154$.

Tschirnhaus M., von. 1992. Minier- und Halmfliegen (Agromyzidae, Chloropidae) und 52 weitere Familien (Diptera) aus Malaise-Fallen in Kiesgruben und einen Vorstadtgarten in Köln. Decheniana - Beihefte. 31: 445-497.

Zakhvatkin A.A. 1954. Parasites of Acrididae of Priangaria. In: Trudy Vsesouznogo entomologicheskogo obshchestva. T. 44 [Proceedings of All-Union Entomological Society. Vol. 44]. Leningrad: 240-300 (in Russian). 